\title{
Radiochemical Verification Technologies for the Detection of Nuclear Explosions - Recent Developments in Radionuclide Monitoring with the Comprehensive Nuclear-Test-Ban Treaty -
}

\author{
Lisa Kokaji*,a and Nobuo Shinohara ${ }^{\mathrm{b}}$ \\ ${ }^{a}$ School of Engineering, The University of Tokyo, 7-3-1 Hongo Bunkyo-ku Tokyo, 113-8656, Japan \\ ${ }^{\mathrm{b}}$ Department of Science and Technology for Nuclear Material Management, Japan Atomic Energy Agency, Tokai, \\ Ibaraki 319-1195, Japan
}

\section{Received: January 11, 2013; In Final Form: April 10, 2014}

\begin{abstract}
The Provisional Technical Secretariat of the Comprehensive Nuclear-Test-Ban Treaty (CTBT) Organization has established the International Monitoring System (IMS) under its auspices. Through technological advances, the CTBT has achieved nuclear test detection limits of 1 kiloton by the use of CTBT verification technologies. However, radionuclides were not observed clearly by the IMS during the first and second nuclear weapon tests conducted by the Democratic People's Republic of Korea (DPRK). With the third test carried out by the DPRK, however, they could observe traces of the event using the IMS, noble gas detection stations, and Atmospheric Transport Modeling (ATM) techniques. After the accident at the Fukushima Dai-ichi Nuclear Power Plant in March 2011, the IMS accurately tracked the global movement of radionuclides that originated from this event. In the following report, the current situation and recent problems regarding environmental monitoring of radionuclides by the CTBT are presented and discussed. Focus will be placed on the detection abilities of the IMS and the system used for evaluation of the radionuclides released by nuclear explosions and power plant accidents.
\end{abstract}

\section{Introduction}

How does the Comprehensive Nuclear-Test-Ban Treaty (hereafter CTBT) monitoring system detect nuclear explosions globally? An adequate verification regime by the CTBT is of vital importance for State Parties in monitoring the peaceful use of nuclear power. Seventeen years have passed since the CTBT was adopted by the United Nations (UN) General Assembly. Eighty seven percent of the CTBT International Monitoring System (IMS) stations were installed by the Provisional Technical Secretariat of the CTBT organization (CTBTO) and the data has been transmitting to the International Data Center (IDC) in Vienna on a provisional basis. ${ }^{1}$ The IMS consists of three wave data verification technologies (infrasound, seismological, and hydroacoustic) and a radionuclide detection system. The presence of radionuclides is the only concrete proof as to whether a nuclear explosion (i.e., the production of radionuclides by a fission event) has occurred. However, the detection of hidden underground nuclear explosions is a challenge as compared to the detection of atmospheric and underwater explosions. This is due to the fact that most of the fissile components (and thus, the radionuclides required for detection) remains in the subterranean cavity formed by an underground nuclear explosion.

The Democratic People's Republic of Korea (DPRK) announced that three nuclear tests had been conducted on October 9, 2006, May 25, 2009, and February 12, 2013. These events were anticipated to provide an adequate proficiency test for the IMS. However, radionuclides were not clearly observed by the IMS in the first and second DPRK tests. During the third event, the IMS could only detect the associated radionuclides after 55 days. In contrast, the detection abilities of the IMS during the Fukushima Dai-ichi Power Plant accident were

*Corresponding author. E-mail: kokaji.lisa@jaea.go.jp found to be more robust. Both during and after this accident, the capability and usefulness of the IMS radionuclide stations were noteworthy, even though the IMS stations were originally established to detect clandestine nuclear explosions. At the Fukushima Dai-chi Nuclear Power Plant accident in March 2011, the quantity of the expanded radionuclides was substantial and some more peculiar radionuclides indicated what had occurred in the containment vessel.

In this report, the recent situation and problems related to environmental monitoring of radionuclides are presented and discussed by focusing on IMS detection abilities, with consideration of the systems used to evaluate radionuclides released by nuclear explosions and accidents.

\section{Monitoring technologies for nuclear explosion detection}

There are four types of monitoring stations that support the CTBT verification regime, as summarized below:

1) Seismic stations: The seismological component of the IMS can detect seismic events and locate their points of origin. This system comprises 50 primary seismic stations, supplemented by 120 auxiliary seismic stations.

2) Hydroacoustic stations: Sound waves produced by natural and man-made phenomena in the world's oceans can be detected by these stations, which are extremely sensitive to explosions and can pick up acoustic waves from underwater events even over transcontinental distances. Due to the efficient transmission of acoustic energy in ocean water, only a few stations are required by the IMS. A total of 11 stations are included in the CTBT global verification regime.

3) Infrasound stations: Sixty of these stations will be built globally, which can detect low-frequency sound waves produced in the atmosphere. This technique can distinguish 
between natural phenomena such as meteorites, volcanic eruptions, and other events, as well as man-made phenomena such as re-entering space debris, rocket launches, and atmospheric explosions.

4) Radionuclide stations: Radioactive particles and gases released from atmospheric, underground or underwater explosions can be detected by these stations. Some 80 radionuclide stations were selected for the radionuclide-monitoring network. These can detect radioactive particles, and half of these stations (40) have radioactive gas detection systems.

In 1963, the Limited Test Ban Treaty banned the testing of nuclear weapons in outer space. After this treaty was implemented, the P-5 countries (permanent member states of the United Nations Security Council: China, France, Russia, the United Kingdom, and the United States) ceased atmospheric nuclear weapons tests, and were only able to resume testing underground. The IMS data derived from the three wave databased technologies cannot detect any absolute evidence of a nuclear test. However, the radionuclide data is unique and can distinguish with certainty as to whether the observed event is a nuclear test.

A total of 321 stations and 16 certified radionuclide laboratories are capable of detecting nuclear explosions taking place underground, within water, and in the atmosphere. The IMS can detect, locate, and identify nuclear explosions of at least one kiloton $(\mathrm{kt})$ yield detonated in any environment within 14 days. Data from the stations is authenticated and sent to the IDC in Vienna, which supports the verification responsibilities of States Parties by providing raw data and their objective products while providing the additional services necessary for effective global monitoring.

The National Academy of Science (NAS) clarified the situa-

TABLE 1: Purposes and plausible achievements for underground testing at various yields in the absence of horizontal proliferation ${ }^{2} *$

\begin{tabular}{|c|c|c|}
\hline Yield (tons of TNT equivalent)** & $\begin{array}{l}\text { Countries of lesser prior nuclear test } \\
\text { experience }\end{array}$ & $\begin{array}{l}\text { Countries of greater prior nuclear test } \\
\text { experience }\end{array}$ \\
\hline $\begin{array}{l}\text { Subcritical experiments (permissible } \\
\text { under the CTBT) }\end{array}$ & $\begin{array}{l}\text { - Equation-of-state studies } \\
\text { - High-explosive lens tests for implosion } \\
\text { weapons } \\
\text { - Development \& certification of simple, } \\
\text { bulky, relatively inefficient unboosted fis- } \\
\text { sion weapons(e.g., gun-type weapon) }\end{array}$ & $\begin{array}{l}\text { - Limited insights relevant to designs for } \\
\text { boosted fission weapons }\end{array}$ \\
\hline $\begin{array}{l}<1 \mathrm{t} \\
\text { (likely to remain undetected) }\end{array}$ & $\begin{array}{l}\text { - Building experience and confidence with } \\
\text { weapons physics experiments }\end{array}$ & $\begin{array}{l}\text { - One-point safety tests } \\
\text { - Validation of some unboosted fission } \\
\text { weapon designs } \\
\text { - Address some stockpile and design code } \\
\text { issues }\end{array}$ \\
\hline $\begin{array}{l}\text { From } 1 \mathrm{t} \text { to }<100 \mathrm{t} \\
\text { (may not be detectable but strongly } \\
\text { location dependent without location) }\end{array}$ & $\begin{array}{l}\text { - One-point safety tests } \\
\text { - Pursue unboosted designs } * * *\end{array}$ & $\begin{array}{l}\text { - Develop low-yield weapons (validation of } \\
\text { some unboosted fission weapon designs } \\
\text { with yield well below a kiloton) } \\
\text { - Possible overrun range for one-point safety } \\
\text { tests }\end{array}$ \\
\hline $\begin{array}{l}\text { From } 100 \mathrm{t} \text { to }<1 \mathrm{kt} \\
\text { Likely to be detected without evasion, } \\
\text { reduced probability of detection with } \\
\text { evasion } \\
\text { (but strong location dependence) }\end{array}$ & $\begin{array}{l}\text { - Pursue improved implosion weapon design } \\
\text { - Gain confidence in certain small nuclear } \\
\text { designs }\end{array}$ & $\begin{array}{l}\text { - Proof tests of compact weapons with yield } \\
\text { up to } 1 \mathrm{kt} \\
\text { - Validate some untested implosion weapon } \\
\text { designs } \\
\text { - Assess stockpile issues and validate some } \\
\text { design codes }\end{array}$ \\
\hline $\begin{array}{l}\text { From } 1 \mathrm{kt} \text { to }<10 \mathrm{kt} \\
\text { Unlikely to be concealable }\end{array}$ & $\begin{array}{l}\text { - begin development of low-yield boosted } \\
\text { fission weapons } \\
\text { - Eventual development and full testing of } \\
\text { some implosion weapons and low-yield } \\
\text { thermonuclear weapons } \\
\text { - Eventual proof tests of fission weapons } \\
\text { with yield up to 10kt }\end{array}$ & $\begin{array}{l}\text { - Development of low-yield boosted fission } \\
\text { weapons } \\
\text { - Development and full testing of some } \\
\text { implosion weapons and low yield thermo- } \\
\text { nuclear weapons } \\
\text { - Proof tests of fission weapons with yield } \\
\text { up to } 10 \mathrm{kt}\end{array}$ \\
\hline $\begin{array}{l}>10 \mathrm{kt} \\
\text { Not concealable }\end{array}$ & $\begin{array}{l}\text { - Eventual development and full testing of } \\
\text { boosted fission weapons and thermonu- } \\
\text { clear weapons or higher-yield unboosted } \\
\text { fission weapons }\end{array}$ & $\begin{array}{l}\text { - Development and full testing of new con- } \\
\text { figurations of boosted fission weapons and } \\
\text { thermonuclear weapons } \\
\text { - Pursue advances strategic weapons } \\
\text { concepts }\end{array}$ \\
\hline
\end{tabular}

* This table is partly revised with table 4-3 in reference 2.

** In this column the committee summarizes the current state of technology for detecting underground nuclear explosions. This summary does not represent any particular sensor network, medium, or location. For example, IMS detection capabilities can be substantially better than what appears in the column for some locations, and detection capability has generally improved over time. *** Limited improvements of efficiency and weight of unboosted fission weapons compared to 1st generation weapons not needing testing. 
tion concerning the nuclear tests performed in 2002 and 2012. Table 1 shows nuclear test explosion yields and intended purposes updated for 2012. ${ }^{2}$ The NAS has concluded the following:

i) The nuclear explosion threshold levels for IMS seismic detection are now well below a magnitude of $1 \mathrm{kt}$.

ii) In at least $50 \%$ of underground nuclear tests near $1 \mathrm{kt}$ or larger, the noble gas xenon may be detectable both offsite and onsite above the detection limits of the IMS, via prompt venting of nuclear test sites and from long term seepage of appreciable noble gases. The seismic detection system of the IMS is complicated by the non-nuclear phenomena generating seismic signals every day. The xenon detection system should therefore be considered a key point for the CTBT verification regime.

\section{Radionuclide network}

3.1. Particle monitoring. In the 80 radionuclide stations, particles released into the atmosphere are collected on a filter in order to measure radioactivity by use of a High PurityGermanium detector (HPGe). The relative abundance of different radionuclides in the collected samples can then be distinguished between those produced by the natural background, a nuclear reactor or a nuclear explosion. A standard event screening of the $\gamma$-ray spectra measured from the samples is performed by identifying each radionuclide and comparing the measurements of fission or activation products in a sample. Each measured spectra is then assigned to a five-level system. Table 2 gives such a standard list of relevant fission products and the activation products for event screening. The basic descriptions of the five assigned levels ${ }^{3}$ are as follows:

TABLE 2: Standard categorization list for particulate samples ${ }^{3}$

\begin{tabular}{|c|c|c|c|c|c|}
\hline \multicolumn{3}{|c|}{ Fission products } & \multicolumn{3}{|c|}{ Activation products } \\
\hline $\begin{array}{l}\text { Fission } \\
\text { product }\end{array}$ & Half-life & $\begin{array}{l}\text { Primary } \gamma \\
\text { energy } \\
(\mathrm{keV})\end{array}$ & $\begin{array}{l}\text { Activation } \\
\text { product }\end{array}$ & Half-life & $\begin{array}{l}\text { Primary } \gamma \\
\text { energy } \\
(\mathrm{keV})\end{array}$ \\
\hline${ }^{91} \mathrm{Sr}$ & $9.63 \mathrm{~h}$ & 1024.3 & ${ }^{24} \mathrm{Na}$ & $14.96 \mathrm{~h}$ & 1368.6 \\
\hline${ }^{91} \mathrm{Y}$ & $58.51 \mathrm{~d}$ & 1204.8 & ${ }^{42} \mathrm{~K}$ & $12.36 \mathrm{~h}$ & 1524.7 \\
\hline${ }^{93} \mathrm{Y}$ & $10.18 \mathrm{~h}$ & 266.9 & ${ }^{46} \mathrm{Sc}$ & $83.79 \mathrm{~d}$ & 889.3 \\
\hline${ }^{95} \mathrm{Zr}$ & $64.02 \mathrm{~d}$ & 756.7 & ${ }^{47} \mathrm{Sc}$ & $3.349 \mathrm{~d}$ & 159.4 \\
\hline${ }^{95} \mathrm{Nb}$ & $34.98 \mathrm{~d}$ & 765.8 & ${ }^{51} \mathrm{Cr}$ & $27.70 \mathrm{~d}$ & 320.1 \\
\hline${ }^{97} \mathrm{Zr}$ & $16.91 \mathrm{~h}$ & 743.4 & ${ }^{54} \mathrm{Mn}$ & $312.1 \mathrm{~d}$ & 834.8 \\
\hline${ }^{99} \mathrm{Mo}$ & $65.94 \mathrm{~h}$ & $140.5 \mathrm{D}$ & ${ }^{57} \mathrm{Co}$ & $271.8 \mathrm{~d}$ & 122.1 \\
\hline${ }^{99 \mathrm{~m}} \mathrm{Tc}$ & $6.01 \mathrm{~h}$ & 140.5 & ${ }^{58} \mathrm{Co}$ & $70.82 \mathrm{~d}$ & 810.8 \\
\hline${ }^{103} \mathrm{Ru}$ & $39.26 \mathrm{~d}$ & 497.1 & ${ }^{59} \mathrm{Fe}$ & $44.50 \mathrm{~d}$ & 1099.2 \\
\hline${ }^{105} \mathrm{Rh}$ & $35.36 \mathrm{~h}$ & 319.1 & ${ }^{60} \mathrm{Co}$ & $5.271 \mathrm{y}$ & 1332.5 \\
\hline${ }^{106} \mathrm{Ru}$ & $373.59 \mathrm{~d}$ & 621.9 & ${ }^{65} \mathrm{Zn}$ & $244.3 \mathrm{~d}$ & 1115.5 \\
\hline${ }^{111} \mathrm{Ag}$ & $7.45 \mathrm{~d}$ & 342.1 & ${ }^{69 \mathrm{~m}} \mathrm{Zn}$ & $13.76 \mathrm{~h}$ & 438.6 \\
\hline${ }^{112} \mathrm{Pd}$ & $21.03 \mathrm{~h}$ & $617.5 \mathrm{D}$ & ${ }^{72} \mathrm{Ga}$ & $14.1 \mathrm{~h}$ & 834.1 \\
\hline${ }^{115 \mathrm{~m}} \mathrm{Cd}$ & $44.6 \mathrm{~d}$ & 933.8 & ${ }^{74} \mathrm{As}$ & $17.77 \mathrm{~d}$ & 595.8 \\
\hline${ }^{115} \mathrm{Cd}$ & $53.46 \mathrm{~h}$ & 336.2 & ${ }^{76} \mathrm{As}$ & $1.078 \mathrm{~d}$ & 559.1 \\
\hline${ }^{125} \mathrm{Sn}$ & $9.64 \mathrm{~d}$ & 1067.1 & ${ }^{84} \mathrm{Rb}$ & $32.77 \mathrm{~d}$ & 881.6 \\
\hline${ }^{125} \mathrm{Sb}$ & $2.76 \mathrm{y}$ & 427.9 & ${ }^{86} \mathrm{Rb}$ & $18.63 \mathrm{~d}$ & 1076.7 \\
\hline${ }^{126} \mathrm{Sb}$ & $12.46 \mathrm{~d}$ & 695.0 & ${ }^{88} \mathrm{Y}$ & $106.7 \mathrm{~d}$ & 1836.1 \\
\hline${ }^{127} \mathrm{Sb}$ & $3.85 \mathrm{~d}$ & 685.7 & ${ }^{89} \mathrm{Zr}$ & $78.41 \mathrm{~h}$ & 909.0 \\
\hline${ }^{128} \mathrm{Sb}$ & $9.01 \mathrm{~h}$ & 743.2 & ${ }^{102} \mathrm{Rh}$ & $207 \mathrm{~d}$ & 475.1 \\
\hline${ }^{129 \mathrm{~m}} \mathrm{Te}$ & $33.6 \mathrm{~d}$ & 695.9 & ${ }^{106 m} \mathrm{Ag}$ & $8.28 \mathrm{~d}$ & 717.2 \\
\hline${ }^{130} \mathrm{I}$ & $12.36 \mathrm{~h}$ & 536.1 & ${ }^{108 \mathrm{~m}} \mathrm{Ag}$ & $418 \mathrm{y}$ & 722.9 \\
\hline${ }^{131 \mathrm{~m}} \mathrm{Te}$ & $30 \mathrm{~h}$ & 773.7 & ${ }^{110 \mathrm{~m}} \mathrm{Ag}$ & $249.8 \mathrm{~d}$ & 657.8 \\
\hline${ }^{131} \mathrm{I}$ & $8.02 \mathrm{~d}$ & 364.5 & ${ }^{120} \mathrm{Sb}$ & $5.76 \mathrm{~d}$ & 1171.7 \\
\hline${ }^{132} \mathrm{Te}$ & $3.20 \mathrm{~d}$ & $772.6 \mathrm{D}$ & ${ }^{122} \mathrm{Sb}$ & $2.724 \mathrm{~d}$ & 564.2 \\
\hline${ }^{133} \mathrm{I}$ & $20.8 \mathrm{~h}$ & 529.9 & ${ }^{124} \mathrm{Sb}$ & $60.20 \mathrm{~d}$ & 602.7 \\
\hline${ }^{135} \mathrm{I}$ & $6.57 \mathrm{~h}$ & 1260.4 & ${ }^{132} \mathrm{Cs}$ & $6.479 \mathrm{~d}$ & 667.7 \\
\hline${ }^{136} \mathrm{Cs}$ & $13.16 \mathrm{~d}$ & 1048.1 & ${ }^{133} \mathrm{Ba}$ & $10.52 \mathrm{y}$ & 356.0 \\
\hline${ }^{137} \mathrm{Cs}$ & $30.07 \mathrm{y}$ & $661.7 \mathrm{D}$ & ${ }^{134} \mathrm{Cs}$ & $2.065 \mathrm{y}$ & 604.7 \\
\hline${ }^{140} \mathrm{Ba}$ & $12.75 \mathrm{~d}$ & 537.3 & ${ }^{152 \mathrm{~m}} \mathrm{Eu}$ & $9.312 \mathrm{~h}$ & 841.6 \\
\hline${ }^{140} \mathrm{La}$ & $1.678 \mathrm{~d}$ & 1596.2 & ${ }^{152} \mathrm{Eu}$ & $13.54 \mathrm{y}$ & 1408 \\
\hline${ }^{141} \mathrm{Ce}$ & $32.50 \mathrm{~d}$ & 145.4 & ${ }^{168} \mathrm{Tm}$ & $93.1 \mathrm{~d}$ & 816.0 \\
\hline${ }^{143} \mathrm{Ce}$ & $33.04 \mathrm{~h}$ & 293.3 & ${ }^{187} \mathrm{~W}$ & $23.72 \mathrm{~h}$ & 685.7 \\
\hline${ }^{144} \mathrm{Ce}$ & $284.9 \mathrm{~d}$ & 133.5 & ${ }^{190} \mathrm{Ir}$ & $11.78 \mathrm{~d}$ & 186.7 \\
\hline${ }^{147} \mathrm{Nd}$ & $10.98 \mathrm{~d}$ & 531.0 & ${ }^{192} \mathrm{Ir}$ & $73.83 \mathrm{~d}$ & 316.5 \\
\hline${ }^{149} \mathrm{Pm}$ & $53.08 \mathrm{~h}$ & 286.0 & ${ }^{196} \mathrm{Au}$ & $6.183 \mathrm{~d}$ & 355.7 \\
\hline${ }^{151} \mathrm{Pm}$ & $28.40 \mathrm{~h}$ & 340.1 & ${ }^{196 m} \mathrm{Au}$ & $9.7 \mathrm{~h}$ & 147.8 \\
\hline${ }^{153} \mathrm{Sm}$ & $46.27 \mathrm{~h}$ & 103.2 & ${ }^{198} \mathrm{Au}$ & $2.695 \mathrm{~d}$ & 411.8 \\
\hline${ }^{155} \mathrm{Eu}$ & $4.761 \mathrm{y}$ & 105.3 & ${ }^{203} \mathrm{~Pb}$ & $51.87 \mathrm{~h}$ & 279.2 \\
\hline${ }^{156} \mathrm{Sm}$ & $9.4 \mathrm{~h}$ & 203.8 & ${ }^{224} \mathrm{Ra}^{\mathrm{b})}$ & $3.66 \mathrm{~d}$ & 241.0 \\
\hline${ }^{156} \mathrm{Eu}$ & $15.19 \mathrm{~d}$ & 1153.7 & ${ }^{237} \mathrm{U}$ & $6.75 \mathrm{~d}$ & 208.0 \\
\hline${ }^{157} \mathrm{Eu}$ & $15.18 \mathrm{~h}$ & 370.5 & ${ }^{239} \mathrm{~Np}$ & $2.357 \mathrm{~d}$ & 277.6 \\
\hline
\end{tabular}

a) $\mathrm{D}$ denotes that the radionuclide is detected through the primary line of the short-lived daughter.

b) ${ }^{224} \mathrm{Ra}$ needs to be screened with respect to the ${ }^{224} \mathrm{Ra} /{ }^{228} \mathrm{Ac}$ ratio. 
Level 1: Typical background. The sample contains only natural or non-relevant anthropogenic radionuclides at normal concentrations.

Level 2: Anomalous background. The sample contains natural or non-relevant anthropogenic radionuclides, but with one or more at abnormal concentrations. Alternatively, the sample contains a non-relevant anthropogenic nuclide which is not normally observed.

Level 3: Normal anthropogenic. The sample contains one or more relevant anthropogenic radionuclides which are often observed at the station, and are at concentrations within normal expected ranges.

Level 4: Anomalous anthropogenic. The sample contains one relevant anthropogenic radionuclide either not normally observed at the station, or at concentrations above the normal expected range.

Level 5: Multiple anthropogenic. The sample contains more than one relevant anthropogenic radionuclide at anomalous concentrations.

Specifications for the IMS stations are based on reports written in 1995 by the Expert Groups of the Ad Hoc Committee. ${ }^{4-6}$ In the case of the radionuclide stations, the technical requirements for the particulate stations are determined by the specifications outlined in Table 3. ${ }^{7}$ Figure 1 shows the global locations of the radionuclide stations. Each station is certified as an IMS station by the CTBTO Provisional Technical Secretariat (PTS), with satisfaction of technical and operational requirements. ${ }^{8}$

A Radionuclide Aerosol Sampler/Analyzer (RASA) is an automatic high-volume system used to sample and analyze the atmosphere for radioactive debris indicative of nuclear weapons testing. The RASA meets CTBT requirements for near-realtime, ultra-sensitive field measurements of short-lived fission products, which permit detection at great distances from a nuclear detonation site. The analyzer passes air through a large-area and low-pressure drop filter at a high flow rate for selectable time periods. It then seals together with bar codes for sample identification and performs a $\gamma$-ray analysis of the filter. The $\gamma$-ray spectrum and auxiliary data, like the meteorological data, are automatically transmitted to the IDC. The filter samples are retained for subsequent analysis.

When the relationship between radioactive decay and ingrowth in a parent-daughter pair such as ${ }^{95} \mathrm{Zr}-{ }^{95} \mathrm{Nb}$ and ${ }^{140} \mathrm{Ba}-$ ${ }^{140} \mathrm{La}$ are measured in a radionuclide station, the timing of the nuclear explosion event can be determined from the daughter/ parent activity ratio. When the number of atoms of the parent nuclide $\left(N_{p}\right)$ at time zero, $N_{p}(0)$, is determined, then $N_{p}$ at any time $t, N_{p}(t)$, can be expressed by the following equation:

$$
N_{p}(t)=N_{p}(0) \cdot \mathrm{e}^{-\lambda p t}
$$

Assuming that the daughter nuclide is produced solely by the

TABLE 3: Specification for the aerosol and particulate monitoring stations ${ }^{7}$

\begin{tabular}{|c|c|}
\hline Characteristics & Minimum requirements \\
\hline System & Manual or automated \\
\hline Air flow & $500 \mathrm{~m}^{3} / \mathrm{h}$ \\
\hline Collection time ${ }^{\text {a) }}$ & $24 \mathrm{~h}$ \\
\hline Decay time ${ }^{\text {b) }}$ & $24 \mathrm{~h}$ \\
\hline Measurement time $^{\mathrm{c})}$ & $20 \mathrm{~h}$ \\
\hline Time before reporting & $3 \mathrm{~d}$ \\
\hline Reporting frequency & Daily \\
\hline Filter & Adequate composition for compaction, dissolution and analysis \\
\hline Particulate collection efficiency & $\begin{array}{l}\text { For filter }: \geq 80 \% \text { at } \Phi=0.2 \mu \mathrm{m} \\
\text { Global }^{\mathrm{d})}: \geq 60 \% \text { at } \Phi=10 \mu \mathrm{m}\end{array}$ \\
\hline Measurement mode & HP Ge High resolution gamma spectrometry \\
\hline HP Ge relative efficiency & $40 \%$ \\
\hline HP Ge resolution & $<2.5 \mathrm{keV}$ at $1332 \mathrm{keV}$ \\
\hline Base line sensitivity ${ }^{e, f)}$ & 10 to $30 \mathrm{~Bq} / \mathrm{m}^{3}$ for ${ }^{140} \mathrm{Ba}$ \\
\hline Calibration range & 88 to $1836 \mathrm{keV}$ \\
\hline $\begin{array}{l}\text { Data format for gamma spectra and } \\
\text { auxiliary data }\end{array}$ & RMS (Radionuclide Monitoring System) format ${ }^{\mathrm{g}}$ ) \\
\hline State of health & Status data transmitted to IDC \\
\hline Communication & Two-way \\
\hline Auxiliary data & $\begin{array}{l}\text { Meteorological data } \\
\text { Flow rate measurement every } 10 \mathrm{~min}\end{array}$ \\
\hline Data availability & $95 \%$ \\
\hline Down time $^{\text {h) }}$ & 7 consecutive days, 15 days annually \\
\hline \multicolumn{2}{|c|}{$\begin{array}{l}\text { a) Time specifications allow for an uncertainty of } 10 \% \text {, except for the reporting time parameter. } \\
\text { b) This value can be reduced, down to a minimum of } 6 \text { hours, if a suspicious event is detected by other sta- } \\
\text { tions or techniques. } \\
\text { c) This value allows for authentication measurements for manual systems. } \\
\text { d) This global value includes the } 80 \% \text { filter efficiency and the collection efficiency of the incoming air cir- } \\
\text { cuitry. } \\
\text { e) The upper limit is intended for high background areas. } \\
\text { f) Certification procedures to be defined for baseline sensitivities (a posteriori MDCs) as well as the effi- } \\
\text { ciency. Sample preparation losses should not affect base line sensitivities. } \\
\text { g) This format should make provision for auxiliary data, authentication data and state of health data. } \\
\text { h) Provision should be made for spare parts in particular areas where periodicity of transportation facilities } \\
\text { is more than } 7 \text { days. }\end{array}$} \\
\hline
\end{tabular}




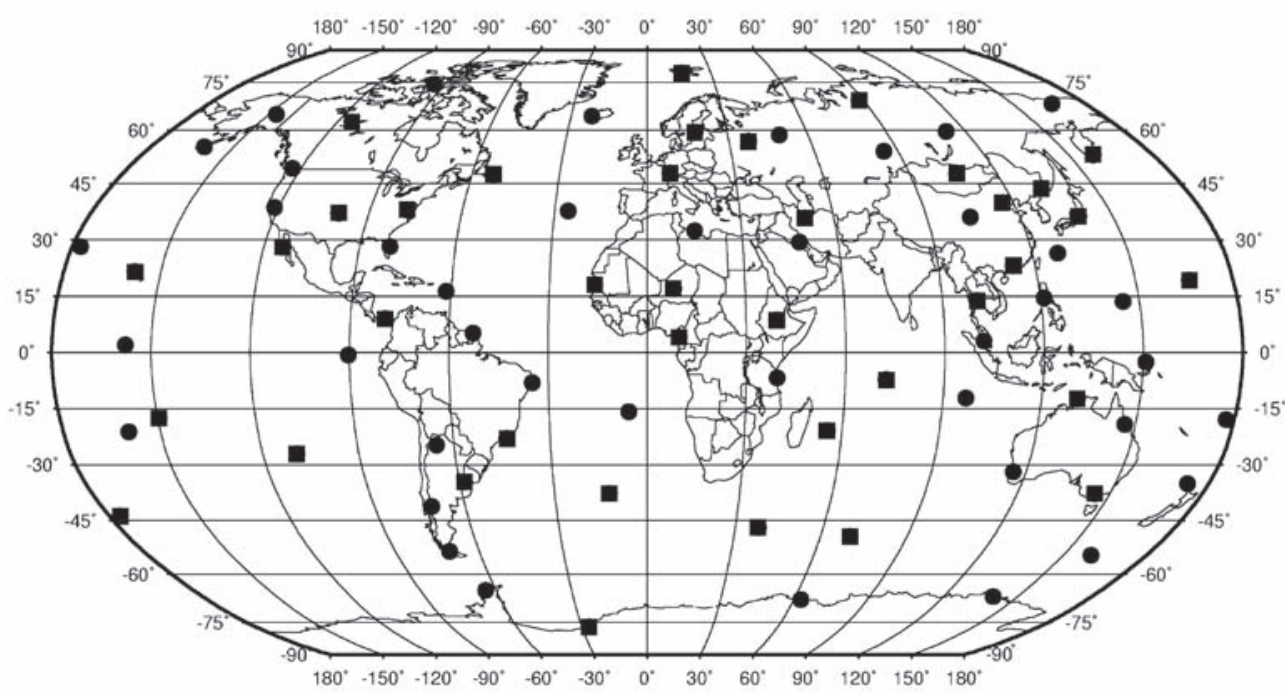

Figure 1. The IMS radionuclide network. Squares represent stations having the ability to monitor radioactive particulate matter and xenon isotopes in the atmosphere. ${ }^{8}$ Circles represent stations with the ability to monitor radioactive particulate matter only.

radioactive decay of the parent nuclide, the number of atoms of the daughter nuclide at time $t, N_{d}(t)$, can be calculated as follows:

$$
N_{d}(t)=\lambda_{p} /\left(\lambda_{d}-\lambda_{p}\right) \cdot N_{p}(0) \cdot\left(\mathrm{e}^{-\lambda p t}-\mathrm{e}^{-\lambda d t}\right)
$$

where $\lambda_{p}$ and $\lambda_{d}$ are the decay constants of the parent and daughter nuclides, respectively. Activity ratios of the daughter and parent nuclides at any time $t, R_{d / p}(t)$, can be obtained from Eqs. (1) and (2):

$$
\begin{aligned}
R_{d / p}(t)= & \left(\lambda_{d} \cdot N_{d}(t)\right) /\left(\lambda_{p} \cdot N_{p}(t)\right) \\
& =\lambda_{d} /\left(\lambda_{d}-\lambda_{p}\right) \cdot\left(1-\mathrm{e}^{-(\lambda d-\lambda p) t}\right)
\end{aligned}
$$

Therefore the time interval, $t$, can be derived from Eq. (3) as follows:

$$
t=-1 /\left(\lambda_{d}-\lambda_{p}\right) \cdot \ln \left(1-R_{d / p}(t) \cdot\left(\lambda_{d}-\lambda_{p}\right) / \lambda_{d}\right)
$$

Figure 2 shows an example of the relationship between activity ratios of ${ }^{95} \mathrm{Nb} /{ }^{95} \mathrm{Zr}$ and time. From the precise measurement of the ${ }^{95} \mathrm{Nb} /{ }^{95} \mathrm{Zr}$ value, the time-zero (elapsed time from a nuclear fission event) can be estimated radiochemically. The time-zero has been considered as an IMS standard for the processing of data from IMS radionuclide stations, together with the five-level assignment applied to the measured radionuclides.

3.2. Noble gas monitoring. Xenon isotopes and their isomers are the radioactive signatures most likely to be observed following a nuclear weapons test, even in the case of underground explosions. ${ }^{9}$ About 20 radioactive isotopes of xenon are formed during fission of heavy elements like uranium or plutonium. Most of these isotopes decay within seconds, but a few $\left({ }^{131 \mathrm{~m}} \mathrm{Xe},{ }^{133 \mathrm{~m}} \mathrm{Xe},{ }^{133} \mathrm{Xe}\right.$, and $\left.{ }^{135} \mathrm{Xe}\right)$ have half-lives of several hours to days, and are produced in amounts that can be detected at great distances from the source of emission. The isotopes of ${ }^{131 \mathrm{~m}} \mathrm{Xe},{ }^{133 \mathrm{~m}} \mathrm{Xe},{ }^{133} \mathrm{Xe}$, and ${ }^{135} \mathrm{Xe}$ have been selected for continuous monitoring by the IMS, which have potential sources as shown in Table 4. There are 40 noble gas stations that will be installed within some of the 80 radionuclide stations (see Figure. 1). The minimum requirements for noble gas monitoring are determined by the CTBTO Preparatory Commission, as stated in Table $5 .^{10}$

Four different systems have been developed to sample and measure noble gases, namely SPALAX (French system, $\gamma$ spectrometry), ARSA (American system, $\beta-\gamma$ coincidence spec-

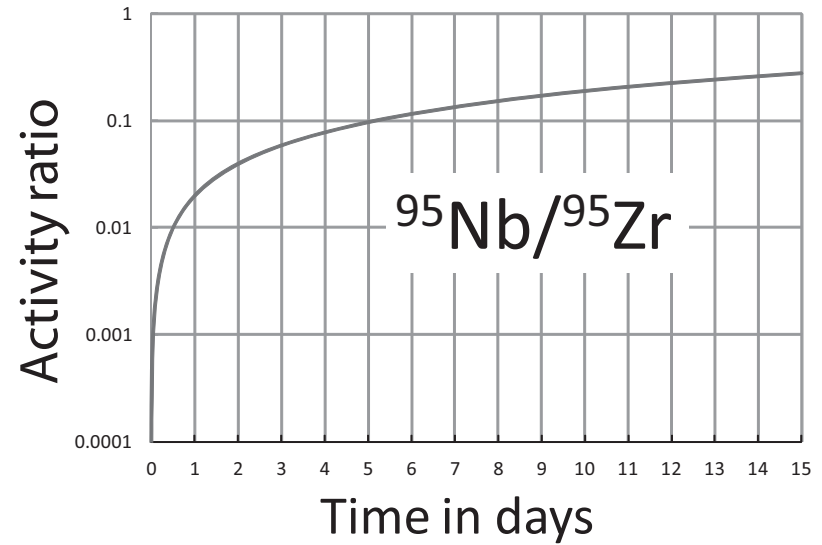

Figure 2. Activity ratio of a pair of parent ${ }^{95} \mathrm{Zr}$ and daughter ${ }^{95} \mathrm{Nb}$ as a function of time elapsed from nuclear explosion.

TABLE 4: Principal potential sources of the radioxenons

\begin{tabular}{l|c|c|c|c}
\hline & ${ }^{131 \mathrm{~m}} \mathbf{X e}$ & ${ }^{133 \mathrm{~m}} \mathbf{X e}$ & ${ }^{133} \mathbf{X e}$ & ${ }^{135} \mathbf{X e}$ \\
\hline $\begin{array}{l}\text { Weapons } \\
\text { testing vent }\end{array}$ & $\mathbf{X}$ & $\mathbf{X}$ & $\mathbf{X}$ \\
\hline $\begin{array}{l}\text { Reactor } \\
\text { operations }\end{array}$ & $\mathbf{X}$ & & $\mathbf{X}$ & \\
\hline $\begin{array}{l}\text { Fuel } \\
\text { reprocessing }\end{array}$ & $\mathbf{X}$ & & $\mathbf{X}$ & \\
\hline $\begin{array}{l}\text { Medical } \\
\text { isotopes }\end{array}$ & & &
\end{tabular}

trometry), SAUNA (Swedish system, $\beta-\gamma$ coincidence spectrometry), and ARIX (Russian system, $\beta$-gated $\gamma$ spectrometry). In parallel, specific analytical software is being developed to examine the spectra produced by these different systems. ${ }^{11}$ The SAUNA ${ }^{12,13}$ system, installed in Takasaki, Japan, consists of three main parts: sampling, processing, and detector units. The sampling unit collects atmospheric xenon over the course of 12 hours via adsorption on activated charcoal. The collected gas is processed further and quantified in the processing unit, and the $\beta$-ray and $\gamma$-ray activities are measured in the detector unit. To distinguish the radioxenon produced by a nuclear explosion from other environmental radioxenon sources, the noble gas background at each station 
TABLE 5: Minimum requirements for noble gas monitoring ${ }^{10}$

\begin{tabular}{|c|c|}
\hline Characteristics & Minimum requirements \\
\hline Airflow & $0.4 \mathrm{~m}^{3} / \mathrm{h}$ \\
\hline Total volume of sample & $10 \mathrm{~m}^{3}$ \\
\hline Collection time & $\leq 24 \mathrm{~h}$ \\
\hline Measurement time & $\leq 24 \mathrm{~h}$ \\
\hline Time before reporting & $\leq 48 \mathrm{~h}$ \\
\hline Reporting frequency & Daily \\
\hline Isotopes measured & ${ }^{131 \mathrm{~m}} \mathrm{Xe},{ }^{133 \mathrm{~m}} \mathrm{Xe},{ }^{133} \mathrm{Xe}$, and ${ }^{135} \mathrm{Xe}$ \\
\hline Measurement mode ${ }^{\text {a) }}$ & Beta-gamma coincidence or high resolution gamma spectrometry \\
\hline Minimum detectable concentration ${ }^{\text {b) }}$ & $1 \mathrm{mBq} / \mathrm{m}^{3}$ for ${ }^{133} \mathrm{Xe}$ \\
\hline State of health & Status data transmitted to IDC \\
\hline Communication & Two-way \\
\hline Data availability $^{\text {c) }}$ & $95 \%$ \\
\hline Downtime & $\leq 7$ consecutive days, $\leq 15$ days annually \\
\hline
\end{tabular}

has to be well understood and studied carefully.

These systems are now undergoing trials at several locations worldwide as a part of the so-called International Noble Gas Experiment (INGE). ${ }^{14}$ The INGE has found that the global radioxenon background is strongly dominated by radiopharmaceutical production facilities. A few major production plants for ${ }^{99} \mathrm{Mo}$ and other medical isotopes currently release an order of magnitude larger amount of ${ }^{133} \mathrm{Xe}$ than the combined output from all of approximately 450 nuclear power reactors that are operational worldwide. Stations in the southern hemisphere or in Arctic regions rarely detect radioxenon, if at all.

3.3. Atmospheric Transport Modeling. Atmospheric Transport Modeling (ATM) uses meteorological data to calculate the travel path of a given radionuclide. This calculation can be used for back tracking, in order to identify the area where a radionuclide may have been released. Forward ATM also predicts where radionuclides may travel from their known point of release, also through the use of meteorological data. ${ }^{15}$ Therefore, ATM can be used in conjunction with IMS radionuclide measurements to trace and locate the original radionuclide release point.
ATM technology played an important role during early CTBT negotiations in estimating the performance of various designs for the global radionuclide monitoring network used for treaty verification. ${ }^{16}$ The models FLEXPART, used by the European Centre for Medium Range Weather Forecasts (ECMWF), and HYSPLIT, used by NOAA (National Oceanic and Atmospheric Administration, United States Department of Commerce) are used operationally for CTBT analyses. . These models also help to determine the coverage and threshold of IMS network monitoring.

\section{Application of the IMS network}

4.1. DPRK nuclear test in 2006. On October 9, 2006, the DPRK government declared that they had conducted a nuclear test. The closest IMS radionuclide particulate stations were located at Takasaki and Okinawa in Japan, and at Sand Point in Alaska. Following the event, they were unable to measure any relevant radionuclides. ${ }^{17}$ At that time, a noble gas station was not installed at the Takasaki station. The activity of ${ }^{133} \mathrm{Xe}$ was only measured at Yellowknife, Canada, as shown in Figure. $3 .^{18}$

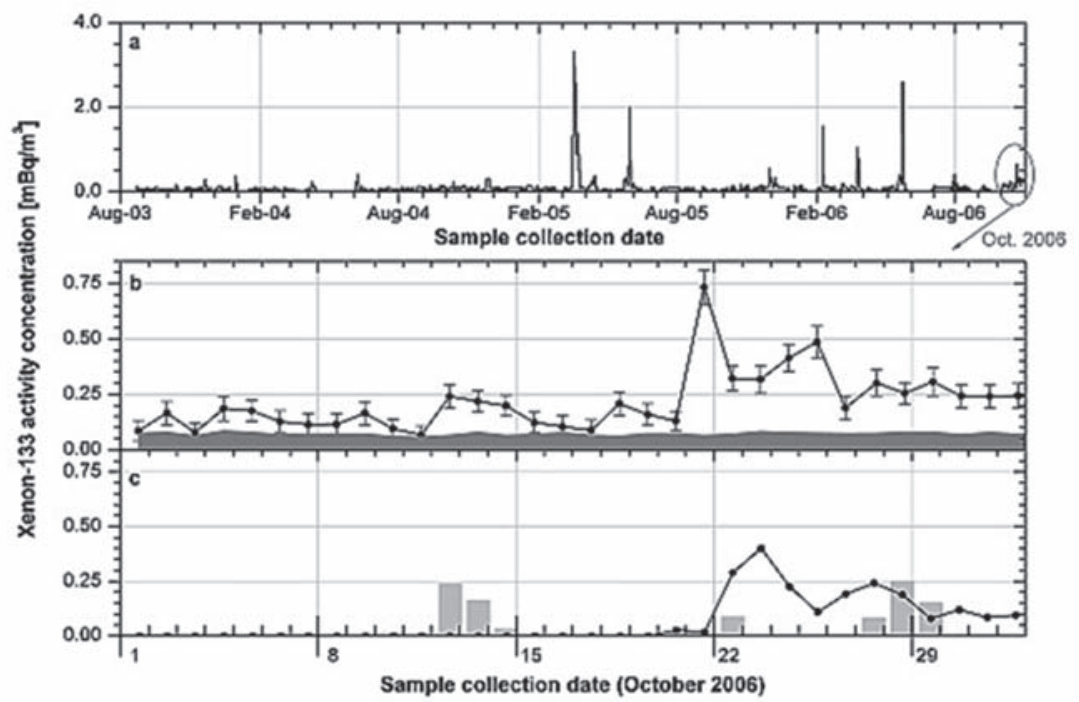

Figure 3. Daily activity concentrations of ${ }^{133}$ Xe measured at Yellowknife, Canada, during three years from 15 August 2003 to 31 October 2006 given in the upper figure (a). ${ }^{18}$ The data measured on October 2006 are enlarged in the middle figure (b), where the continuous grey pattern represents the minimum detectable concentration of ${ }^{133} \mathrm{Xe}$. The FLEXPART model was applied to the event on 9 October 2006 by assuming the emission of $1 \mathrm{PBq}$ of ${ }^{133} \mathrm{Xe}$ from the DPRK test site and the calculated results are shown in the lower figure (c), where the small grey histogram shows the contribution of the facility in Chalk River Laboratory of Atomic Energy of the Canada Limited. 
The FLEXPART model was applied as an ATM model based on wind data provided by the ECMWF. ${ }^{18}$ According to FLEXPART calculations, the radionuclides would have reached the nearest operating noble gas station in Yellowknife, Northern Canada, on October 22, 2006, resulting in a strong peak on the $23 \mathrm{rd}$ and a relatively weak peak on the 27 th (see Figure. $3 \mathrm{c}$ ). However, the observations of ${ }^{133} \mathrm{Xe}$ in the Yellowknife station were two days ahead (see Figure. 3 b). It can be seen from Figure. 3 a that there have been 5 peaks of even greater radionuclide concentrations since 2003. Regardless, the CTBTO concluded that the detection of the DPRK test by the Yellowknife station was an excellent demonstration for the IMS and showed that noble gas stations are capable of providing evidence of a nuclear explosion. ${ }^{17}$

Since the 2006 test, it is clear that radionuclide stations, including those tracking noble gases, can provide unique proof of a nuclear event. However, the observation data from October 2006 was not definitive, as it did not show the highest radionuclide peaks as observed by the Yellowknife station. Furthermore, there are many operational nuclear power plants and radioisotope production facilities in the northern hemisphere. In fact, high ${ }^{133} \mathrm{Xe}$ levels have been occasionally observed and traced back to emissions from the Chalk River Laboratory, built in Ontario, Canada for the purposes of radiomedical radioisotope production. ${ }^{18}$ If the two day time lag as seen in Figure. 3 can be predicted by the global dispersion model, a more detailed evaluation is necessary to detect clandestine nuclear tests.

4.2. DPRK nuclear test in 2009. The government of the DPRK claimed that another nuclear test had been conducted on May 25, 2009. However, none of the radionuclide stations detected a visible signal that could be attributed to a nuclear explosion. Figure 4 shows the evolution of the detectable radioactive plume, as calculated for an immediate venting scenario and plotted at the times when the greatest concentration of the radioactive plume arrived at each station. ${ }^{19}$ Three of the radionuclide stations shown in Figure. 4 were operating continuously at full performance. Their overall detection capability (Minimum Detectable Concentration, MDC) was $0.2 \mathrm{mBq} / \mathrm{m}^{3}$ or better throughout the relevant time period. ${ }^{19}$ By utilizing calculations based on the assumption that the containment rate corresponds to the full release of radioactive ${ }^{133} \mathrm{Xe}$, as generated by a $4 \mathrm{kt}$ TNT equivalent explosion $\left(4 \times 10^{16} \mathrm{~Bq}\right)$, the explosion magnitude scale should measure 4.52 rather than 4.1 , as measured in $2006 .^{20}$

In the case of $90 \%$ radionuclide containment, the detectable plume would cover the shaded area in Figure. 4. For a containment of $99.9 \%$, the detectable plume would cover only the areas inside of the shaded region. Since the stations located in this zone did not record signals at corresponding times, it was concluded that the containment of any generated xenon was above $99.9 \%{ }^{19}$, assuming that this was indeed a nuclear test. The IMS coverage was intended to detect a nuclear explosion of $1 \mathrm{kt}$ magnitude or greater, and the 2009 nuclear explosion at the DPRK test site was evaluated to be more than $4 \mathrm{kt}$. However, this event also highlights the difficulties involved with using radionuclide stations to detect nuclear explosions with absolute certainty.

4.3. DPRK nuclear test in 2013. On February 12, 2013, the DPRK announced that a third nuclear test was conducted. After 55 days following that announcement, i.e., April 8 and 9, 2013, ${ }^{131 \mathrm{~m}} \mathrm{Xe}$ and ${ }^{133} \mathrm{Xe}$ were detected at Takasaki station and lower levels were picked up by another station in Ussuriysk, Russia. The CTBTO press center stated that the CTBTO has detected radioactivity consistent with the February 12 announcement of a North Korean nuclear test. According to this article, the ratio of the detected xenon isotopes is consistent with a nuclear fission event occurring more than 50 days prior to the detection. Using ATM on the basis of weather

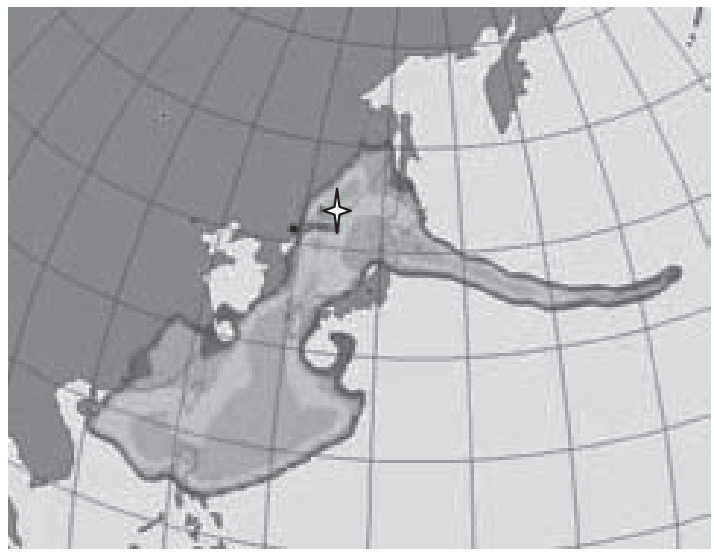

(1)RN58

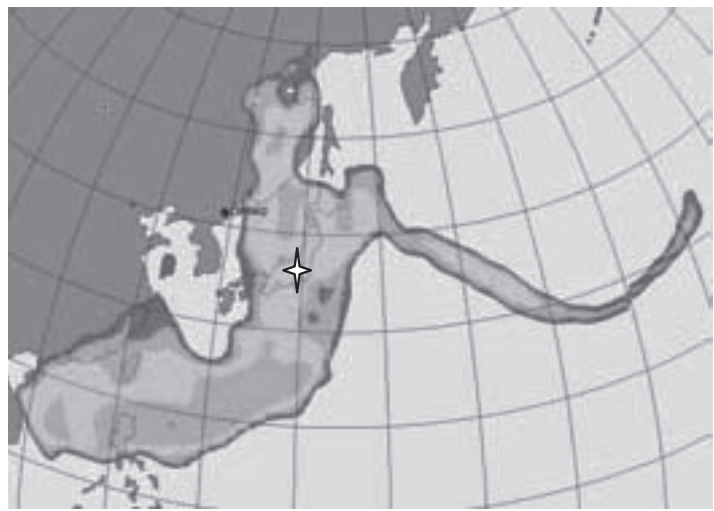

(2) $\mathrm{RN} 38$

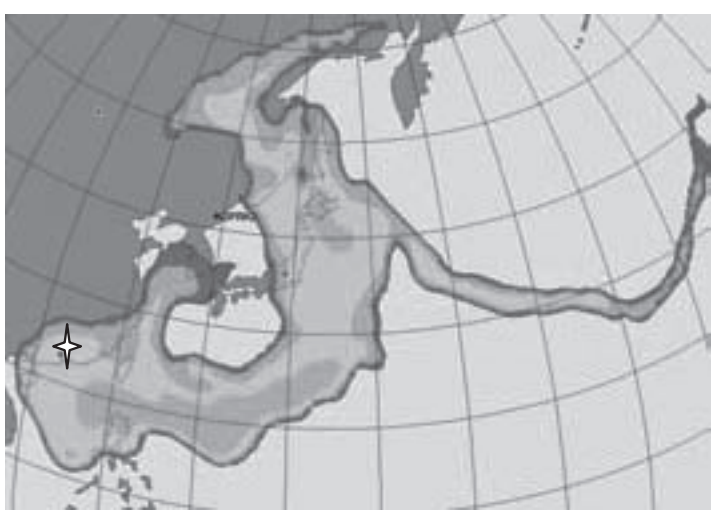

(3) $\mathrm{RN} 22$

Figure 4. Evolution of the detectable radioactive plume as calculated for an immediate venting scenario, plotted at the times of the strongest arrivals at (1) RN58, USSURIYSK Russian Federation at 30 May 2009, 12 UTC, (2) RN38, TAKASAKI Japan at 31 May 2009, 21 UTC, and (3) RN22, GUANZHOU China at 2 June 2009, 0 UTC. $^{19}$ Mark $\&$ shows each station location.

data, the DPRK test site was identified as a possible source for the emissions. ${ }^{21}$

4.4. Fukushima Dai-ichi Nuclear Power Plant disaster. The accident at Fukushima Daiichi Nuclear Power Station was caused by the loss of reactor core cooling functions and the prolonged simultaneous loss of all power, due to the 13 meterhigh tsunami brought about by the massive M9.0 earthquake on March 11, 2011. What followed after the tsunami was a serious accident in which a number of explosions occurred at the reactor buildings, releasing radioactive materials into the atmosphere and ocean. ${ }^{22}$

The first analytical results of the IMS monitoring data were available a few days after the accident. Initial detection of radioactive materials were made on March 12 by the Takasaki monitoring station in Japan, located about $200 \mathrm{~km}$ from the nuclear power plant. The dispersion of the radioactive isotopes 


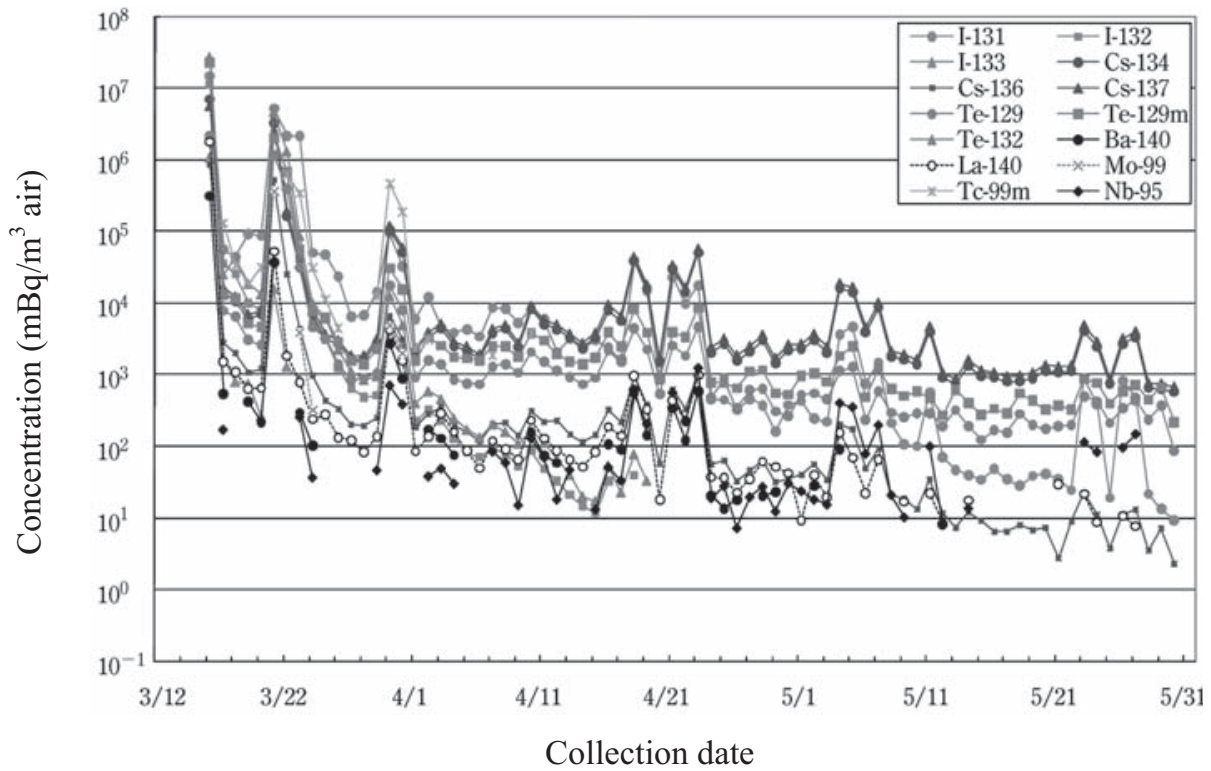

Figure 5. Monitoring results of the radionuclide particles measured at Takasaki station from 12 March to 31 May $2011 .{ }^{24}$

were then tracked to eastern Russia on March 14, and to the west coast of the United States two days later. ${ }^{23}$ Isotopes of ${ }^{131} \mathrm{I}$ and ${ }^{137} \mathrm{Cs}$ were detected continuously at the Takasaki station and reported to the IDC (see Figure. 5). ${ }^{24}$ Filters from March 13 and 14 were contaminated by the radioactive plume which arrived on March 15. On March 16, data from the previous day had been expected, but nothing was received due to a scheduled blackout. For this reason, data from March 12 to 15 does not appear on Figure. 5. The early detection of ${ }^{95} \mathrm{Nb}$ and ${ }^{103} \mathrm{Ru}$ was a timely indicator of a meltdown inside one or more of the reactors at Fukushima. ${ }^{25}$ By March 15, traces from the accident in Fukushima were detectable all across the northern hemisphere. By April 13, the associated radioactivity had spread to the southern hemisphere of the Asia-Pacific region and was clearly detectable at CTBT IMS stations located in Australia, Fiji, Malaysia, and Papua New Guinea.

\section{Discussion}

The wave detection capability of the IMS using the infrasound method will provide $95 \%$ global coverage and a better detection capability for nuclear explosions of yields equal to, or greater than, $0.9 \mathrm{kt}^{26}$ For example, a $0.02 \mathrm{kt}$ TNT explosion occurring on the continental shelf off the coast of Japan was detected more than 16,000 km across the Pacific Ocean by a hydroacoustic station. ${ }^{27}$ Following the DPRK test in 2006, the CTBTO announced that they could detect the nuclear explosion mainly through seismology stations. The CTBTO also reported that nuclear test traces of the radioactive noble gas ${ }^{133} \mathrm{Xe}$ had been detected by the Canadian station in Yellowknife, as mentioned in Section. 4.1. However, it seems that the Yellowknife station data could not be used as absolute evidence of the DPRK nuclear test, since the environmental xenon concentrations are high in that area due to the presence of nuclear facilities that produce large quantities of noble gas. After the second test by the DPRK in 2009, the 39 seismic stations registered a signal measuring 4.52 on the Richter scale at 00:54 GMT. ${ }^{28}$ However, radioxenon gas or particles were not detected by radionuclide stations in Japan, although the Takasaki noble gas station had been installed after the first nuclear test in 2006. There are two possibilities as to why no radionuclide signals were detected: (i) the DPRK did not conduct a nuclear test, or (ii) all fission products were mostly sealed up by the collapse of heated sand and rock, and therefore more than $99.9 \%$ of the radionuclides were contained underground. The radionuclide observations will strongly depend on three environmental factors: i) how much radioactive material is released, ii) how the gases or particles are carried by wind, and iii) the sensitivity of the detection system itself.

In the case of the Fukushima accident, worldwide attention has focused on, and recognized, the importance of ATM. Stohl et al. ${ }^{29}$ determined that atmospheric emissions of two isotopes, the noble gas ${ }^{133} \mathrm{Xe}$ and the aerosol particle ${ }^{137} \mathrm{Cs}$, have very different release characteristics and behavior in the atmosphere. By using the results of the atmospheric transport model FLEXPART $^{28}$ and measurement data from several dozen IMS stations in Japan, North America, and other regions, a total release of 15.3 (uncertainty range of $12.2-18.3$ ) EBq of ${ }^{133} \mathrm{Xe}$ was estimated to be derived from structural damage to reactor components and/or leaks due to overpressure. For ${ }^{137} \mathrm{Cs}$, the results give a total emission of 36.6 (20.1-53.1) PBq, which may have also originated in part from the spent-fuel pool of unit 4 of the Fukushima Dai-ichi Nuclear Power Plant, in addition to the damaged reactor cores. These evaluations can be picked out by the ATM model, which has been used as a tool for CTBT verification. Terada et al. ${ }^{30}$ analyzed the regionalscale atmospheric dispersion and surface deposition of ${ }^{131} \mathrm{I}$ and ${ }^{137} \mathrm{Cs}$ during the Fukushima accident using the WSPEEDI-II simulation. The results suggest that the present surface deposition distribution of ${ }^{137} \mathrm{Cs}$ over eastern Japan was produced mainly by wet and/or dry deposition in several areas of the country.

\section{Conclusion}

In order to improve the present detection abilities of the CTBT IMS, the ATM models mentioned above must be put to practical use. The simulation models of FLEXPART ${ }^{29}$ used for CTBT global environmental modeling and WSPEEDI-II ${ }^{30}$ will give more specific and detailed information. The DPRK nuclear test in 2013 demonstrated the importance of ATM information. The CTBT radionuclide stations also revealed an ability to monitor the worldwide effects of the Fukushima nuclear disaster. Furthermore, to improve radionuclide detection abilities and for immediate detection following a nuclear explosion, increasing the number of noble gas stations will be necessary. Furthermore, some radionuclides are of importance for the clarification of emergency situations, as they provide a radiological perspective that can help ascertain the internal damage of a compromised nuclear power plant. Even though 
the CTBT has not yet entered into force, the IMS technology is vital for maintenance of the present moratorium by State Parties, and for nuclear accident preparation. The way in which each State Party utilizes these IMS framework technologies will be important in the future, depending on each country's role and contributions.

\section{Acknowledgements}

The authors would like to thank Prof. Satoru Tanaka for his comprehensive advice on conducting this research and Prof. Yusuke Kuno for his instructive comments on the manuscript. They also extend thanks to Mr. Yoshiharu Kagawa for his valuable advice, Mr. Tetsuzo Oda for his technical advice, and Dr. Chushiro Yonezawa for his practical help on the description of the paper.

\section{References}

(1) CTBTO publication, Annual Report 2011, (2012), p.2.

(2) National Research Council, The Comprehensive Nuclear Test Ban Treaty Technical Issues for the United States, (The National Academies Press, Washington, D.C. 2012), p.116.

(3) K. M. Matthews, L-E. De Geer, J. Radioanal. Nucl.Chem. 263, 235 (2005).

(4) Conference on Disarmament, Report of the Expert Group based on Technical Discussions held from 4 through 15 December 1995, CD/NTB/WP.283, 20 December (1995).

(5) Conference on Disarmament, Report of the Expert Group based on Technical Discussions held from 22 to 25 August 1995, CD/NTB/WP.269, 15 September (1995).

(6) Conference on Disarmament, Report of the Expert Group based on Technical Discussions held from 6 February to 3 March 1995, CD/NTB/WP.224, 16 March (1995) and CD/ NTB/WP.224/Corr.2, 13 September (1995).

(7) Second Session of the Preparatory Commission for the CTBTO, CTBT/PC/II/1.Add.2, (1997), p.48.

(8) Fausto Medici, Radiat. Phys Chem. 61, 689 (2001).

(9) Martin B. Kalnowski, Andreas Becker, Paul R. J. Saey, Matthias P. Tuma, Gerhard Wotawa, COMPLEXITY 14, 89 (2008).

(10) Second Session of the Preparatory Commission for the CTBTO, СТВT/PC/II/1.Add.2, (1997), p.49.

(11) P.R.J. Saey, L.E.De Geer, Appl. Radiat. Isot. 63, 765 (2005).

(12) A. Ringbom, T. Larson, A. Axelsson, K. Elmgren, C. Johansson, Nucl. Instrum. Methods. A508, 542 (2003).

(13) T.W. Bower, S. R. Biegalski, M. Cooper, P. W. Eslinger, D. Haas, J .C. Hayes, H. S. Miley, D. J. Strom, V. Woods, J.
Environ. Radioact. 102, 681 (2011).

(14) M. Auer, A. Axelsson, X. Blanchard, T. W. Bowyer,G. Brachet, I. Bulowski, Y. Dubasov, K. Elmgren, J. P.Fontaine, W. Harms, J. C. Hayes, T. R. Heimbigner, J. I.McIntyre, M. E. Panisko, Y. Popov, A. Ringbom, H. Sartorius,S. Schmid, J. Schulze, C. Schlosser, T. Taffary, W. Weiss, B. Wernsperger, Appl. Radiat. Isot. 60, 863 (2004).

(15) CTBTO homepage, Glossary, http://www.ctbto.org/ glossary $/$ ?letter $=\mathrm{a} \& \mathrm{cHash}=4 \mathrm{~d} 181 \mathrm{e} 9 \mathrm{a} 0 \mathrm{c} \# \mathrm{~atm}$.

(16) Peter Chen, Richard Hogue, CTBTO International Scientific Studies 09, Science for Security, edited by Ola Dahlman (CTBTO, Vienna, 2009), p.30.

(17) Paul R.J. Saey, Andreas becker, Gerhard Wotawa, CTBTO SPECTRUM 10, 20 (2007).

(18) P. R. J. Saey, M. Bean, A. Becker, J. Coyne, R. d'Amours, L.-E. De Geer, R. Hogue, T. J. Stocki, R. K. Ungar, G. Wotawa, Geophys. Res. Lett., 34, L20802, (2007).

(19) Robert G. Pearce, Andreas Becker, Tim Hampton, Matthias Zahringer, CTBTO publication CTBTO SPCTRUM 13, 26 (2009).

(20) CTBTO homepage, Information Centre Press Release, http://www.ctbto.org/press-centre/press- releases/2009/ctbtos-initial-findings-on-the-dprks-2009-announced-nucleartest/.

(21) CTBTO homepage, Information Centre Press Release, http://www.ctbto.org/press-centre/press-releases/2013/ ctbto-detects-radioactivity-consistent-with-12-februaryannounced-north-korean-nuclear-test/.

(22) Tokyo Electric Power Company homepage, Fukushima Daiichi- A One Year Review, http://www.tepco.co.jp/en/nu/ fukushima-np/review/index-e.html.

(23) CTBTO homepage, Fukushima Related Measurements by the CTBTO, http://www.ctbto.org/press-centre/highlights/2011/fukushima-related-measurements-by-the-ctbto/

(24) C. Yonezawa, Y. Yamamoto, Bunseki 8, 451 (2011).

(25) Wolfgang Weiss, CTBTO SPECTRUM 17, 27 (2011).

(26) Elisabeth Blanc, Lars Ceranna, CTBTO International Scientific Studies 09, Science for Security, edited by Ola Dahlman (CTBTO, Vienna, 2009), p.15.

(27) Wolfgang Jans, Kiyoshi Suyehiro, ibid. p.19.

(28) CTBTO homepage, Democratic People's Republic of Korea, http://www.ctbto.org/the-treaty/developments-after1996/2009-dprk-announced-nuclear-test/.

(29) A. Stohl, P. Seibert, G. Wotawa, D. Arnold, J. F. Burkhart, S. Eckhardt, C. Tapia, A. Vargas, T. J. Yasunari, Atmos. Chem. Phys. 12, 2313 (2012).

(30) H. Terada, G. Katata, M. Chino, H. Nagai, J. Environ. Radioact. 112, 141 (2012). 
